\title{
Die Septuaginta - Texte, Theologien, Einflüsse
}

\author{
2. Internationale Fachtagung veranstaltet von Septuaginta Deutsch (LXX.D), \\ Wuppertal 23.-27. Juli 2008 \\ Hrsg. v. Wolfgang Kraus u. Martin Karrer unter Mitarb. v. Martin Meiser
}

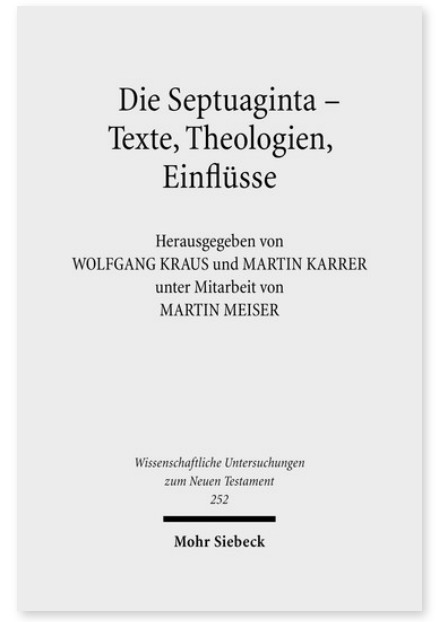

2010. XI, 750 Seiten. WUNT I 252

ISBN 978-3-16-151541-5

DOI 10.1628/978-3-16-151541-5

eBook PDF $184,00 €$

ISBN 978-3-16-150225-5

Leinen $184,00 €$
Die Septuaginta ist als jüdische Bibelübersetzung ab dem 3. Jh. v.Chr. entstanden. Sie wird von den meisten neutestamentlichen Autoren als Grundlage ihrer Schriftzitate benutzt und ist das Alte Testament in den Orthodoxen Kirchen. Sie gibt Einblick in das Schriftverständnis des Griechisch sprechenden Judentums. Die Septuaginta-Forschung bildet einen eigenständigen Bereich neben der Erforschung der Hebräischen Bibel. Historischer Ort, Textgeschichte, literarische Einbettung und Theologie der Septuagintaschriften stellen die Wissenschaft vor viele offene Fragen, deren Antworten im internationalen Forschungskontext gesucht werden. Der vorliegende Band enthält Studien zum historischen Hintergrund der Septuaginta, zur Textgeschichte, zur Philologie, zu Einzelproblemen von Septuaginta-Schriften und zur Rezeption der Septuaginta. Er gibt einen Überblick über den gegenwärtigen Forschungsstand und zeigt Perspektiven für weitere Forschung auf. Der Band ist erwachsen aus einer Tagung des Projektes Septuaginta Deutsch, die im Juli 2008 in Wuppertal stattfand.

\section{Inhaltsübersicht}

Allgemeines und Geschichte Emanuel Tov: What is the Septuagint? - Adrian Schenker: Warum wurde die Tora im 3. Jahrhundert in Alexandrien auf griechisch übersetzt? Eine Prüfung der bisherigen Erklärungen und eine neue Antwort - Gilles Dorival: New Light about the Origin of the Septuagint? - Armin Lange: Textliche Standardisierung in der griechischen Texttradition und der Bibliothek von Alexandria - Arie van der Kooij: The Old Greek of Isaiah and Other Prophecies in Egypt of the Time - Johannes Enge/s: Syrien, Phönikien und Judäa in den Geographika Strabons von Amaseia (Strab. Geog. 16,2,1-46) Textgeschichte

Siegfried Kreuzer: Übersetzung - Revision - Überlieferung. Probleme und Aufgaben in den Geschichtsbüchern - Martin Karrer: Codex Sinaiticus Judges - Robert V. Hiebert: Establishing the Textual History of Greek 4 Maccabees - Marcus Sigismund/Ulrich Schmid/Martin Karrer: Textgeschichtliche Beobachtungen zu den Zusätzen in den Septuaginta-Psalmen Michae/ N. van der Meer: The Question of the Literary Dependence of the Greek Isaiah upon the Greek Psalter Revisited Peter Gentry: Issues in the Text-History of LXX Ecclesiastes - Heinz-Josef Fabry: »Der Herr macht meine Schritte sicher « (Hab 3,19 Barb.) - Die Versio Barberini, eine liturgische Sondertradition von Hab 3 - Gert J. Steyn: Recently Discovered New Testament Papyri and their Value in the Reconstruction of LXX Texts - Martin Meiser: Hieronymus als Textkritiker - Cameron Boyd-Taylor: The Greek Bible in Byzantine Judaism. Evidence from the Margins of Christian Manuscripts - Marcus Sigismund: Text- und theologiegeschichtliche Anmerkungen zu den LXX-Zitaten in der gotischen Bibelübersetzung Lexikographie und Übersetzungstechnik

Takamitsu Muraoka: From the Desk of a Septuagint Lexicographer - Anna Passoni dell'Acqua: Translating as a Means of Interpreting: The Septuagint and Translation in Ptolemaic Egypt - Christoph Kugelmeier: 'Voces biblicae' oder 'voces communes'? Zum Sprachgebrauch der Septuaginta im Lichte neuerer Papyrusforschungen - Hans Ausloos /Bénédicte Lemmelijn: Content Related Criteria in Characterising the LXX Translation Technique - Jan Joosten: »Al tiqré« as a Hermeneutic Device and the Septuagint Translation - Jong-Hoon Kim: Die griechische Übersetzung für db[ in Samuel- und Königebücher Eberhard Bons: Seltene Wörter in der Septuaginta des Amosbuches - Pierre-Maurice Bogaert: Baal au féminin et les divinités féminines dans Jérémie LXX - Katrin Hauspie: The Reception of the Septuagint-version of Ezekiel by Theodoret of Cyrrhus: a Philological Approach

Theologie und Religionsgeschichte

Martin Rösel: Tempel und Tempellosigkeit. Der Umgang mit dem Heiligtum in der Pentateuch-LXX - Helmut Utzschneider: Die Septuaginta als Erzählerin - Beobachtungen an der Exoduserzählung - Natalio Fernández Marcos: Jephtah's Daughter in the Old Greek - Philippe Hugo: Abner der Königsmacher versus David den gesalbten König - Beate Ego: Zur religiösen Vorstellungswelt in den »Zusätzen zu Ester « - Albert Pietersma: Psalm 15(16) in Greek: Its Production and Reception - Mario Cimosa: Angels, Demons and the Devil in the Book of Job (LXX) - William R. Loader: The Seductress: Image and Reality in Proverbs and Ben Sira, Hebrew and Greek - Cécile Dogniez: La necromancie dans la Septante d'Isaïe - Johann Cook: Interpreting the Septuagint - Exegesis, Theology and/or Religionsgeschichte? - Timothy McLay: Why not a Theology of the Septuagint?

\section{Wirkungsgeschichte}

Jutta Leonhardt-Balzer: Philo und die Septuaginta - Mogens Müller: Josephus und die Septuaginta - Cilliers Breytenbach: LXX Jes 53,6.12 und die urchristliche Hingabeformel - Jan Dochhorn: Das Testament Hiobs als Produkt narrativer Exegese. Eine Studie zur Wirkungsgeschichte des griechischen und hebräischen Hiobbuchs - Jean-Marie Auwers: The Greek Song of Songs as Found and Interpreted in the Exegetical Catenae - Riemer Roukema: Patristic Interpretation of Micah - Wolfgang Kraus: Erträge der Tagung und das geplante Handbuch zur Septuaginta

Martin Karrer ist Professor für Neues Testament an der Kirchlichen Hochschule Wuppertal.

Wolfgang Kraus Born 1955; 1990 doctorate; 1994 Habilitation; Professor emeritus for New Testament Studies at the University of the Saarland, Saarbruecken.

Martin Meiser Born 1957; 1983-91 Lutheran minister in Bavaria; 1991-2001 Assistant for New Testament in Erlangen; 200105 Assistant for Early Church History in Mainz; 2005-07 Vicarious Professor in Münster/Westphalia; since 2007 Associate 
Professor in Saarbrücken.

Jetzt bestellen:

https://mohrsiebeck.com/buch/die-septuaginta-texte-theologien-einfluesse-9783161515415?no_cache=1 order@mohrsiebeck.com

Telefon: +49 (0)7071-923-17

Telefax: $+49(0) 7071-51104$

Mohr Siebeck GmbH \& Co. KG

Postfach 2040

D-72010 Tübingen

info@mohrsiebeck.com

Mohr Siebeck

www.mohrsiebeck.com 